\title{
PENGAWASAN PENYELENGGARAAN PELAYANAN PUBLIK DALAM PEMERINTAH DESA
}

\author{
Oleh : \\ Fatkhurohman *
}

\begin{abstract}
Public service is part of social basic to the citizens/ it is through public service that the government do its responsibility to meet needs and to try to improve its peoples prosperity. One of the facilities is to improve public service to villagers through a regulation on village namely the 2014 law No. 6 on village, stating that the regulation on villages is intended to improve the public service for villagers to accelerate the realization of a public prosperity. This article is intended to discuss the mechanism in giving public services in village government. Based on the normative method, it can be concluded that the supervision of public service in village government was not explicitly stated. This supervision should be made to prevent any misuses of authority.
\end{abstract}

Kata Kunci: pelayanan publik, pemerintahan desa, penyalahgunaan wewenang.

\section{Pendahuluan}

Pasca disahkannya Undang-Undang Nomor 6 Tahun 2014 tentang Desa, maka desa mempunyai kedudukan hukum yang cukup kuat, jika sebelumnya pengaturan mengenai desa diatur dalam ketentuan Pasal 200 sampai dengan Pasal 216 UndangUndang Nomor 32 Tahun 2004 tentang Pemerintahan Daerah. Namun setelah tanggal 15 Januari 2014 pengaturan tentang desa dalam susunan dan tata cara penyelenggaraan pemerintahan dan pembangunan diatur melalui undang-undang tersendiri. Salah satu tujuan yang melatarbelakangi pengaturan desa, sebagaimana dicantumkan dalam ketentuan Pasal 4 huruffUndang-Undang Nomor6 Tahun 2014 bahwa pengaturan desa bertujuan meningkatkan pelayanan publik bagi warga masyarakat desa guna mempercepat perwujudan kesejahteraan umum.

Secara konstitusional ketentuan Pasal 4 huruff Undang-Undang Nomor 6 Tahun 2014 tersebut merupakan penjabaran amanat dari ketentuan Pasal 18 Aayat (2) dan Pasal 34 ayat (3) UUDNRI 1945. Pasal 18 A ayat (2) menyatakan bahwa hubungan keuangan, pelayanan umum, pemanfaatan sumber daya alam dan sumber daya lainnya antara pemerintah pusat dan pemerintah daerah diatur dan dilaksanakan secara adil dan selaras berdasarkan undangundang. Pasal 34 ayat (3) menyatakan Negara bertanggung jawab atas penyediaan fasilitas pelayanan kesehatan dan fasilitas pelayanan umum yang layak.

* Dosen Fakultas Hukum Universitas Widyagama Malang

$$
\text { Pengawasan Penyelenggaraan Pelayanan . . . 161 }
$$


Dari ketentuan konstitusi diatas peningkatan pelayanan publik harus mendapatkan perhatian utama dari pemerintah, karena pelayanan publik (public service) merupakan hak-hak sosial dasar dari masyarakat (social rights). ${ }^{1}$ Pelayanan public dalam kaitannya dengan hak sosial dasar warga Negara (social rights) merupakan the rights to service, hakhak untukmenerima dari pemerintah seperti hak untuk mendapatkan pendidikan dan pengajaran, hak untuk mendapatkan pekerjaan yang layak bagi kemanusiaan, jaminan hukum yang adil serta perlakuan yang sama dihadapan hukum, dan jaminan sosial. ${ }^{2}$

Dengan demikian jelas bahwa konstitusi telah mengamanatkan secara tegas tentang pelayanan publik sebagai wujud hak sosial dasar, yang wajib diselenggarakan untuk menuju sebuah Negara kesejahteraan berdasarkan amanat UUDNRI 1945. Pemerintah dalam bingkai Negara ketatalaksanaan (administrative state) senantiasa dipertalikan dengan citacita Negara kesejahteraan (welfare state). ${ }^{3}$ Berangkat dari pandangan Negara kesejahteraan, pemerintah mempunyai peran yang cukup besar tidak lagi hanya membuat dan mempertahankan hukum namun lebih luas lagi yaitu menyelenggarakan kepentingan umum dalam mewujudkan kesejahteraan rakyatnya. ${ }^{4}$ Pemerintah turut aktifdalam pemenuhan dan penyelenggaraan kepentingan umum seperti kesehatan, pendidikan, perumahan, pemenuhan kebutuhan pangan pembagian tanah dan lain sebagainya. ${ }^{5}$

Dalam ketentuan Undang-Undang Nomor 25 Tahun 2009 tentang Pelayanan Publik pada bagian menimbang butir b menyebutkan bahwa pembangunan kepercayaan masyarakat atas pelayanan publik yang dilakukan penyelenggara pelayanan publik merupakan kegiatan yang harus dilakukan seiring dengan harapan dan tuntutan seluruh warga Negara dan penduduk tentang peningkatan pelayanan publik. Sebagai upaya untuk meningkatkan pelayanan publik tersebut melalui penyelenggaraan pemerintahan desa diharapkan dapat meningkatkan pelayanan publik bagi warga masyarakat desa guna mempercepat

\footnotetext{
${ }^{1}$ Philipus M. Hadjon, et.al., Hukum Administrasi dan Tindak Pidana Korupsi, (Yogyakarta: Gajah Mada University Press, 2011), hlm. 26.

${ }^{2}$ Ibid.

${ }^{3}$ M. Solly Lubiş Asas-Asas Hukum Tata Negara, (Bandung Alumni, 1982), hlm. 31.

${ }^{4}$ Kuncoro Purbopranoto, Beberapa Catatan Hukum Tata Pemerintahan dan Peradilan Administrasi Negara, (Bandung: Alumni, 1984) hlm. 41

${ }^{5}$ Utrecht. E., Pengantar Hukum Administrasi Negara, Cet. Ke. 4, (Bandung: Ihctiar, 1960), hlm. 22-23.
}

perwujudan kesejahteraan umum termasuk melalui penataan desa.

Sebagaimana Pasal 7 ayat (3) hurufc dan ayat (4) Undang-Undang Nomor 6 Tahun 2014 tentang Desa, Penataan desa melalui pembentukan, penghapusan, penggabungan, perubahan status dan penetapan desa diarahkan untuk mempercepat peningkatan pelayanan publik. Sebagai upaya meningkatkan pelayanan publik bagi warga masyarakat desa, disertai dengan kewenangan desa sebagaimana ditegaskan dalam ketentuanPasal 19 Undang-Undang Nomor 6 Tahun 2014 sebagai berikut:

a. Kewenangan berdasarkan hak asal usul;

b. Kewenangan lokal berskala desa;

c. Kewenangan yang ditugaskan oleh Pemerintah, Pemerintah Daerah Provinsi, atau Pemerintah Daerah Kabupaten/Kota; dan

d. Kewenangan lain yang ditugaskan oleh Pemerintah, Pemerintah Daerah Provinsi, atau Pemerintah Daerah Kabupaten/Kota sesuai dengan ketentuan peraturan perundang-undangan.

Lebih lanjut sebagai peraturan pelaksanaan Undang-Undang Nomor 6 Tahun 2014 tentang desa yaitu Pasal 34 Peraturan Pemerintah Nomor 43 Tahun 2014 tentang Peraturan Pelaksanaan UndangUndang Nomor 6 Tahun 2014 tentang Desa menegaskan bahwa:

(1) Kewenangan Desa berdasarkan hak asal-usul sebagaimana dimaksud Pasal 33 huruf a palinf sedikit terdiri atas:

a. Sistem organisasi masyarakat desa;

b. Pembinaan kelembagaan masyarakat desa;

c. Pembinaan lembaga dan hukum adat;

d. Pengelolaan tanah kas desa; dan

e. Pengembangan peran masyarakat desa.

(2) Kewenangan lokal bersekala Desa sebagaimana dimaksud dalam Pasal 33 hurufb paling sedikit terdiri atas kewenangan:

a. Pengelolaan tambatan perahu;

b. Pengelolaan pasar desa;

c. Pengelolaan tempat pemandian umum;

d. Pengelolaan jaringan irigasi;

e. Pengelolaan lingkungan permukiman masyarakat desa; 
f. Pembinan kesehatan masyarakat dan pengelolaan pos pelayanan terpadu;

g. Pengembangan dan pembinaan sanggar seni dan belajar;

h. Pengelolaan perpustakan desa dan taman bacaan;

i. Pengelolaan embung desa;

j. Pengelolaan air minum beskala desa; dan

k. Pembuatan jalan desa antar permukiman ke wilayah pertanian;

(3) Selain kewenangan sebagaimana dimaksud pada ayat (1) dan ayat (2) menteri dapat menetapkan jenis kewenangan Desa sesuai dengan situasi, kondisi, dan kebutuhan lokal.

Berdasarkan kewenangan yang melekat tersebut, pemerintahan desa melalui peyelenggaraan urusan pemerintahan dan kepentingan masyarakat setempat dalam sistem pemerintahan Negara Kesatuan Republik Indonesia diharapkan mampu untuk meningkatkan pelayanan publik kepada masyarakat desa.

Berdasarkan pemaparan diatas dalam memberikan pelayanan publik dalam era pemerintahan desa, maka dibutuhkan pengawasan insentif dan sistemik terhadap penyelengaraan pelayanan publik di desa. Pengawasan tersebut dimaksudkan untuk mencegah segala bentuk penyimbangan tugas penyelenggaraan pemerintahan desa dari apa yang telah digariskan (prventif) dan menindak atau memperbaiki segala penyimpangan yang terjadi (represif). Oleh karena itu dalam penelitian ini penulis tertarik untuk mengetahui secara lebih mendalam peranan pengawasan penyelenggaraan pelayanan publik dalam pemerintahan desa melalui sebuah penelitian yang berjudul "pengawasan penyelenggaraan pelayanan publik dalam pemerintahan desa"

\section{Rumusan Masalah}

Berdasarkan latar belakang tersebut, permasalahan yang hendak dikaji dalam tulisan ini adalah pengaturan mekanisme pengawasan pelayanan publik dalam pemerintahan desa. Oleh karena itu dari isu hukum diatas, maka pertanyaan hukumnya adalah apakah pengaturan mekanisme pengawasan pelayanan publik dalam pemerintahan desa dapat dibenarkan dari segi pemenuhan hak sosial kepada masyarakat desa?

\section{Metode Penelitian}

Mengingat ini adalah penelitian hukum, maka metode yang dilakukan adalah metode penelitian hukum yang bertujuan untuk mencari pemecahan atas isu hukum serta permasalahan yang timbul di dalamnya, sehingga hasil yang akan dicapai kemudian adalah memberikan preskripsi mengenai apa yang seyogyanya atas isu yang diajukan. ${ }^{6}$ Peter $\mathrm{M}$. Marzuki dalam bukunya Penelitian Hukum, menyatakan bahwa penelitian hukum merupakan proses untuk menemukan aturan hukum, prinsip prinsip hukum maupun doktrin-doktrin hukum guna menjawab isu hukum yang dihadapi.

Pendekatan masalah yang akan digunakan dalam penelitian hukum ini adalah pendekatan undangundangan (statute approach), dan pendekatan konseptual (Conceptual approach). Pendekatan undang-undang (statute approach) dilakukan dengan menelaah semua undang-undang dan regulasi yang bersangkut paut pelayaan publik dan pengaturan mengenai desa. Sedangkan pendekatan konseptual beranjak dari pandangan dan doktrin-doktrin yang berkembang di dalam ilmu hukum. Dengan mempelajari pandangan-pandangan dan doktrindoktrin terebut merupakan sandaran bagi penelitian dalam membangun suatu argumentasi hukum dalam memecahkan isu hukum yang dihadapi. Pendekatan konseptual digunakan untuk mengkaji dan menganalisis kerangka pikir atau kerangka konseptual maupunlandasan teoritissesuai dengan tujuan penelitian.

Bahan hukum primer dan bahan hukum skunder yang telah dikumpulkan (inventarisasi) kemudian dikelompokkan dan dikaji dengan pendekatan perundang-undangan guna memperoleh gambaran sinkronisasi dari semua bahan hukum. selanjutnya dilakukan sistimasi dan klasifikasi kemudian dan dikaji serta dibandingkan dengan teori prinsip hukum yang dikemukakan oleh para ahli, untuk akhirnya dianalisa secara normatif.

\section{Hasil dan Pembahasan}

Pelayanan publik merupakan fungsi dari tanda hadirnya Negara dalam tata masyarakat moderndemokratis. Dengan demikian pelayanan publik bukan hanya sekedar perkara managerial dan teknis

${ }^{6}$ Peter Mahmud Marzuki, Penelitian Hukum, (Jakarta : Kencana Prenada Media Group, 2005), hlm. 35. 
administratifpemerintahan. Melalui pelayanan publik, Negara menyelenggarakan tanggungjawab yang bersifat imperatifkepada rakyat. Secara substansi pelayanan publik berarti upaya memenuhi berbagai hak dasar dan hak berkembang masyarakat. Sementara dari segi proses harus pula mencerminkan asas-asas penyelenggaraan pemerintahan yang dewasa ini dikenal sebagai praktik good dovernance. ${ }^{7}$

Pasal 1 butir 1 Undang-Undang Nomor 25 Tahun 2009 tentang Pelayanan Publik menerangkan bahwa yang dimaksud dengan pelayanan public adalah kegiatan atau rangkaian kegiatan dalam rangka pemenuhan kebutuhan pelayanan sesuai dengan peraturan perundang-undangan bagi setiap warga Negara dan penduduk atas barang, jasa, dan/atau pelayanan administratifyang diselenggarakan oleh penyelenggara pelayanan public. Dari ketentuan Pasal 1 ayat 1 tersebut dengan tegas disebutkan tentang pelayanan public dilakukan atas barang, jasa, dan/atau pelayaan administratif.

Seperti halnya yang diatur dalam ketentuan Pasal 5 Undang-Undang Nomor 25 Tahun 2009 tentang Pelayanan Publik yang mengaskan bahwa ruang lingkup pelayanan publik meliputi pelayanan barang public dan jasa public serta administratifyang diatur berdasarkan undang-undang. Adapun yang dimaksud dengan pelaksana pelayanan publik adalah pejabat, pegawai, petugas dan setiap orang yang bekerja di dalam organisasi penyelenggaran yang bertugas melaksanakan tindakan atau serangkaian tindakan pelayan publik.

Dalam kajian hukum administrasi, konsep pelayanan publik (public service) dikemukakan oleh John Bell yang menerangkan bahwa the public service was activity of the state (later extended to local government and public corporation). In brave public service is a legal structure by which a need of public interest is satisfied. ${ }^{8}$

Lebih lanjut terdapat 4 (empat) elemen penting dalam pelayanan public yaitu sebagai berikut:

a. The purpose for which an activity is under taken (the public interest).

${ }^{7}$ Bambang Soetono, et.al., ed., Kajian dan Rekomendasi Peningkatan Kualitas 'Substansi, Proses, Harmonisasi dan Sinkronisasi Perda Pelayanan Publik, (Jakarta: Kementerian Perencanaan Pembangunan Indonesia/Badan Perencanaan Pembangunan Nasional Republik Indonesia, 2010), hlm. 11.

${ }^{8}$ Brown L. Neville and John S. Bell, French Administration Law, (Oxford: Clarendon Press, 1998), hlm. 168. b. The institution which decides it of to be under taken (the state or another public body);

c. The mechanism by which this is under taken (the use of public power, la puissance publique, or contrac;

d. And those who are involved in providing the service (the civil service, la function publique, or private person) ${ }^{9}$

Pelayanan public meentukan tindakan-tindakan yang tepat bagi para pegawai dan para menteri seperti halnya dalam pemerintahan daerah dan badan-badan swasta. Sebagai perbandingan dalam sistem hukum Prancis dalam melaksanakan fungsi pelayaan pebulik (mission de service public) dilandasi oleh pandangan Rolland Principles yang meliputi Continuity, Adaptability, Equality of user, Neutrality. ${ }^{10}$

1. Continuity

Adalah kontinuitas dalam ketentuan hukum tentang pelayanan, mengikuti tindakan yang diperlukan dalam kepentingan public. Apabila hal tersebut benar-benarmerupakan kepentingan publik, masyarakat diberi pengharapan bahwa pelayanan publik telah tersedia.

2. Adaptability

Adaptability mensyaratkan bahwa pejabat pemerintah harus dapat merubah spesifikasi pelayanan sesuai dengan perubahan-perubahan kepentingan publik. Dalam perjanjian-perjanjian privat, kesucian kontrak, atau persetujuanpersetujuan adalah nilai-nilai yang dominan, dan ini berarti bahwa meruah suatu konstruksi kontrak atau suatu persetujuan pelayanan harus dibuat berdasarkan kesepakatan dalam hukum publik, kepentingan publik adalah yang paling utama, sehingga persyaratan-persyaratan tentang hal tersebut dapat dipaksakan pada kontraktor.

3. Equality of user

Equality of user adalah aspek umum ketatanegaraan mengeni prinsip persamaan dalam pelayanan public. Dalam hal suatu tindakan dilakukan atas barang-barang yang seluruhnya adalah barang publik, dan semua relevan dengan public harus mengakses pada persamaan pelayanan dan diperlukan secara sama unuk itu.

\footnotetext{
${ }^{9}$ Ibid.

${ }^{10}$ Ibid., hlm. 169-170.
} 
4. Neutrality

Netralitas merefleksikan cara Negara liberal yang tidak sekedar mencari untuk menentukan ide kehidupan yang baik bai warga Negara, tetapi lebih jauh lagi adalah untuk memfasilitasi pilihan-pilihan tentang perbedaan cara hidup.

Secara konseptual, tujuan pelayanan pada dasarnya adalah untuk memuaskan masyarakat, untuk mencapai kepuasan itu dituntut kualitas pelayanan prima yang tercermin dari:

1. Transparansi, yakni pelayanan yang bersifat terbuka, mudah dan dapat diakses oleh semua pihak yang membutuhkan dan disediakan secara memadai serta mudah dimengerti;

2. Akuntabilitas, yakni pelayanan yang dapat dipertanggungjawabkan sesuai dengan ketentuan peraturan perundang-undangan;

3. Kondisionil, yakni pelayanan yang sesuai dengan kondisi dan kemampuan pemberi dan penerima pelayanan dengan tetap berpegang pada prinsip efisiensi dan efektivitas;

4. Partisipatif, yaitu pelayanan yang dapat mendorong peran serta masyarakat dalam penyelenggaraan pelayanan publik dengan memperhatikan aspirasi, kebutuhan dan harapan masyarakat;

5. Kesamaan hak, yaitu pelayanan yang tidak melakukan diskriminasi dilihat dari aspek apapun khususnya suku, ras, agama, golongan, status sosial dan lain-lain;

6. Keseimbangan hak dan kewajiban, yaitu pelayanan yang mempertimbangkan aspek keadilan antara pemberian dan penerimapelayanan publik. ${ }^{11}$

Lebih lanjut dalam kajian hukum administrasi pelayanan publik dan pemerintah (termasuk badan pemerintah lain) merpakan dua aspek yang saling terkait. Pemerintah dalam karakter aktifnya dituntut untuk menyeleggarakan tugas-tugas pemerintahan (pelayanan publik) yang semakin beragam dan rumit, sesuai dengan wewenang yang dimiliki. Hal tersebut merupakan keharusan oleh karena itu hakikat hukum administrasi adalah hukum yang berkaitan dengan wewenang pemerintah, dan control terhadap penggunaan wewenang yang tujuannya untuk melindungi individu atau masyarakat. Berbagai definisi tentang

${ }^{11}$ Lijan Poltak Sinabela, Reformasi Pelayanan Publik, Teori Kebijakan dan Implementasi, (Jakarta: Bumi Aksara, 2006), hlm. 6. hukum administrasi menjelaskan tentang wewenang pemerintahan dan bagaimana pengawasan terhadap penggunaan wewenang pelayanan publik dilakukan. ${ }^{12}$

Konteks pengawasan dalam penggunaan wewenang di kemukakan oleh $\mathrm{H}$. B. Jacobini yang mengemukakan pandangannya, bahwa definition of administrative law contain several or all of the following components: control of administration, the legal rules, both internal and external, emerging from administrative agencies, the concern and procedures pertinent to remedying legal injury to individual caused by government entities and their agents, and court decisions pertinent to all or to parts oh these. ${ }^{13}$

Dari keterangan diatas menunjukkan bahwa pentingnya pengawasan atau control penggunaan wewenang pemerintah, prosedur yang tepat bagi upaya hukum terhadap individu yang mengalami penderitaan karena penggunaan wewenang, dan putusan pengadilan yang pantas terhadap hal tersebut. Oleh karena itu jelas bahwa pengawasan merupakan suatu instrument hukum administrasi yang harus mendapatkan perhatian dalam pelayanan publik. Penggunaan wewenang pemerintahan tanpa suatu pengawasan, potensial terhadap terjadinya tindakan penyalah gunaan wewenang atau penggunaan wewenang yang tidak sebaai mestinya.

Dalam konteks hukum administrasi, lingkup mal administrasi tidak semata-mata terjadi karena perilaku menyimpang seperti diuraikan diatas, namun dalam penertian yang lebih luas terjadi karena ide yang tidak benar atau tidak bagus ataupun pertimbangan yang tidak rasional. Hal ini terkait dengan kemampuan atau kecakapan pejabat dalam menilai rasionalitas tindakan pemerintahan ataupun dalam membuat keputusan, beberapa contoh tentang hal tersebut meliputi:

a. Gagal dalam mengambil pertimbangan-pertimbangan yang relevan;

b. Gagal dalam menjalankan peraturan-peraturan hukum yang ada;

c. Gagal dalam meletakkan stau menguji prosedur pemerintahan yang ada;

${ }^{12}$ Philipus M. Hadjon, et.al., Op.cit., hlm. 39.

${ }^{13}$ Ibid., hlm. 40. 
d. Gagal memuat suatu aturan hukum yang baik atau suatu kebijakan yang baik. ${ }^{14}$

Oleh karena itu dalam pendekatan fungsional maladministrasi merupakan rumusan yang negatif, dalam menentukan apakah dalam pelayanan publik pemerintahan desa telah terjadi penyimpangan-penyimpangan yang berakibat pada tindakan korupsi, kolusi, dan nepotisme. Hal ini memerlukan kontrol, untuk menhindari terjadinya penyimpangan.

Landasan hukum yang langsung menyebut tentang pencegahan dan penyelesaian maladministrasi diatur dalam Undang-Undang Nomor 37 Tahun 2008 tentang Ombudsman Republik Indonesia, Pasal 4 urufd, menegaskan bahwa Ombudsman bertugas:

a. Menerima laporan atas dugaan maladministrasi dalam penyelenggaraan pelayanan publik;

b. Melakukan investigasi atas prakarsa sendiri terhadap dugaan maladministrasi dalam penyelenggaraan pelayanan publik

c. Melakukan upaya pencegahan maladministrasi dalam penyelenggaraan pelayanan publik.

Lebih lanjut terdapat kriteria yang menjadi kategori mal administrasi sebagaimana yang dikemukakan Ombusdman, yang meliputi:

1. Perilaku dan perbuatan melawan hukum;

2. Perilaku dan perbuatan melampaui wewenang;

3. Menggunakan wewenang untuk tujuan lain dari yang menjadi tujuan wewenang tersebut;

4. Kelalaian;

5. Pengabaian kewajiban hukum dalam penyelenggaraan pelayanan publik;

6. Dilakukan oleh penyelenggara Negara dan pemerintahan;

7. Menimbulkan kerugian materiil dan/atau immaterial bagi masyarakat dan orang perseorangan..$^{15}$

Meski dalam penyelenggaraan pemerintahan ataupun pelayanan publik telah ada prinsip-prinsip pemerintahan yang baik (AUPB) atau good governance disamping landasan peraturan perudang-

${ }^{14}$ Philipus M. Hadjon, et.al., Hukum Administrasi dan Tindak Pidana Korupsi, op.cit., hlm. 43.

15 Tyas Dian Anggraeni, " Menciptakan Sistem Pelayanan Publik Yang Baik: Strategi Reformasi Birokrasi Dalam Pemberantasan Korupsi" Jurnal Rechtsvinding Media Pembinaan Hukum Nasional, (Pusat Penelitian dan Pengembangan Sistem Hukum Nasional Badan Pembinaan Hukum Nasional Volume 3 Nomor 3, Desember 2014), undangan, namun dalam penggunaan wewenang pemerintahan masih sering terjadi kesalahan-kesalahan dan penimpangan-penyimpangan seperti korupsi, kolusi, dan nepotisme dan bentuk-bentuk mal administrasi yang lain. Hal ini menunjukkan bahwa peran pengawasan belum mendapat perhatian seperti yang dikehendaki oleh peraturan perundangundangan yang ada. Maladministrasi merupakan pelayanan yang jelek atau buruk. Maladministrasi dikaikan dengan tindakan menyimpang dari aparat yang tidak mengindahkan atau tidakmengikuti normanorma perilaku yang baik. ${ }^{16}$

Dalam penyelenggaraan pemerintahan desa, yang mengatur pencegahan terjadinya penyalagunaan wewenang dalam pelayanan publik diatur dalam ketentuan Pasal 29 Undang-Undang Nomor 6 Tahun 2014 tentang Desa yang menegaskan bahwa Kepala Desa dilarang:

a. merugikan kepentingan umum;

b. membuat keputusan yang menguntungkan diri sendiri, anggota keluarga, pihak lain, dan/atau golongan tertentu;

c. menyalahgunakan wewenang, tugas, hak, dan/ atau kewajibannya;

d. melakukan tindakan diskriminatifterhadap warga dan/atau golongan masyarakat tertentu;

e. melakukan tindakan meresahkan sekelompok masyarakat Desa;

f. melakukan kolusi, korupsi, dan nepotisme, menerima uang, barang, dan/atau jasa dari pihak lain yang dapat memengaruhi keputusan atau tindakan yang akan dilakukannya;

g. menjadi pengurus partai politik;

h. menjadi anggota dan/atau pengurus organisasi terlarang;

i. merangkap jabatan sebagai ketua dan/atau anggota Badan Permusyawaratan Desa, anggota Dewan Perwakilan Rakyat Republik Indonesia, Dewan Perwakilan Daerah Republik Indonesia, Dewan Perwakilan Rakyat Daerah Provinsi atauDewan PerwakilanRakyat Daerah Kabupaten/ Kota, dan jabatan lain yang ditentukan dalam peraturan perundangan-undangan;

${ }^{16}$ Philipus M. Hadjon, et.al., Hukum Administrasi dan Good Governance, (Jakarta: Universitas Trisakti, 2010), hlm. 74. 
j. ikut serta dan/atau terlibat dalam kampanye pemilihan umum dan/atau pemilihan kepala daerah;

k. melanggar sumpah/janji jabatan; dan

1. meninggalkan tugas selama 30 (tiga puluh) hari kerja berturut-turut tanpa alasan yang jelas dan tidak dapat dipertanggungjawabkan.

Meskipun dalam ketentuan Pasal 29 UndangUndang Nomor 6 Tahun 2014 diatas merupakan aturan hukum yang melandasi upaya pemerintah untuk mencegah terjadinya korupsi dalam pelayanan publik di tingkat desa. Namun dalam ketentuan Undang-Undang Nomor 6 Tahun 2014 tidak diatur secara jelas mengenai mekanisme evaluasi kenerja pelayanan publik yang disediakan oleh pemerintahan desa sebagai upaya pengawasan pelayaan publik. Jika merujuk pada ketentuan Undang-Undang Nomor 2 Tahun 2015 tentang Penetapan Peraturan Pemerintah Pengganti Undang-Undang Nomor 2 Tahun 2014 tentang Pemerintahan Daerah Menjadi Undang-Undang, ketentuan Pasal 352 yang menegaskan bahwa:

(1) Menteri melakukan evaluasi kinerja pelayanan publik yang dilaksanakan oleh Pemerintah Daerah provinsi.

(2) Gubernur sebagai wakil Pemerintah Pusat melakukan evaluasi kinerja pelayanan publik yang dilaksanakan oleh PemerintahDaerah kabupaten/ kota.

(3) Evaluasi yang dilakukan oleh Menteri dan gubernur sebagai wakil Pemerintah Pusat sebagaimana dimaksud pada ayat (1) dan ayat (2) merupakan bagian dari evaluasi penyelenggaraan Urusan Pemerintahan yang menjadi kewenangan Daerah.

(4) Hasil evaluasi sebagaimana dimaksud pada ayat (3) digunakan oleh Pemerintah Pusat untuk memberikan insentif dan disinsentif fiskal dan/atau non-fiskal kepada Daerah.

Jika sebelumnya disebutkan bahwa salah satu tujuan pengaturan desa adalah untuk meningkatkan pelayanan publik bagi warga masyarakat Desa guna mempercepat perwujudan kesejahteraan umum, sudah seharusnya pengaturan menganai pelayanan publik dan mekanisme pengawasan pelayanan publik pada pemerintahan desa diatur secara jelas dalam ketentuan peraturan perundang-undangan. Tanpa diatur mengenai pengawasan pelayanan publik di tingkat pemerinahan desa justru ini akan menjadi lading baru untuk melakukan praktik korupsi.

\section{Penutup}

Pelayanan publik merupakan kebutuhan dasar sosial masyarakat yang harus dipenuhi, yang merupakan bagian dari hak asasi manusia yang diatur di dalam ketentuan UUDNRI 1945. Pelayanan publik dalam kaitan hak sosial dasar warga Negara merupakan hak-hak untuk menerima dari pemerintah. Pengaturan tentang desa melalui Undang-Undang Nomor 6 Tahun 2014 tentang desa diarahkan untuk meningkatkan pelayanan publik bagi warga masyarakat desa guna mempercepat perwujudan kesejahteraan umum. Pelaksanaan pelayanan publik sebagai hak-hak sosial dasar masyarakat di dalam realita masih banyak terjadi hambatan dan penyimpangan dalam praktiknya.

Salah satunya ialah tidak diaturnya mengenai mekanisme pengawasan penyelenggaraan pelayanan publik dalam pemerintahan desa. Pemerintah mempunyai tugas yang luas dalam pelayanan publik, bersamaan dengan kebutuhan masyarakat yang semakin meningkat khususnya masyarakat desa. Sehubungan dengan kondisi itu, pemerintah dalam karakter aktifnya harus mengambil tindakan. Dengan demikian diperlukan pengawasan penggunaan wewenang dalam pelayanan publik untuk mencegah terjadinya penyalahgunaan wewenang dalam penyelenggaraan pemerintahan desa.

\section{Daftar Pustaka}

Bambang Soetono, et.al., ed., Kajian dan Rekomendasi Peningkatan Kualitas Substansi, Proses, Harmonisasi dan Sinkronisasi Perda Pelayanan Publik, Jakarta: Kementerian Perencanaan Pembangunan Indonesia/Badan Perencanaan Pembangunan Nasional Republik Indonesia, 2010.

Brown L. Neville and John S. Bell. French Administration Law, Oxford: Clarendon Press, 1998.

Kuncoro Purbopranoto, Beberapa Catatan Hukum Tata Pemerintahan dan Peradilan Administrasi Negara, Bandung:Alumni, 1984. 
Lijan Poltak Sinabela, Reformasi Pelayanan Publik, Teori Kebijakan dan Implementasi, Jakarta:Bumi Aksara, 2006.

M. Solly Lubis, Asas-Asas Hukum Tata Negara, Bandung Alumni, 1982.

Peter Mahmud Marzuki. Penelitian Hukum, Jakarta: Kencana Prenada Media Group, 2005.

Philipus M. Hadjon, et.al: Hukum Administrasi dan Tindak Pidana Korupsi, Yogyakarta: Gajah Mada University Press. 2011. , et.al., Hukum Administrasi dan Good Governance, Jakarta:Universitas Trisakti, 2010.

Tyas Dian Anggraeni, “ Menciptakan Sistem Pelayanan Publik Yang Baik: Strategi Reformasi Birokrasi Dalam Pemberantasan Korupsi" Jurnal Rechtsvinding Media Pembinaan Hukum Nasional, Pusat Penelitian dan Pengembangan Sistem Hukum Nasional Badan Pembinaan Hukum Nasional Volume 3 Nomor 3, Desember 2014

Utrecht. E., Pengantar Hukum Administrasi Negara, Cet. Ke. 4, Bandung: Ihctiar, 1960.

Indonesia, Undang-Undang Pelayanan Publik, UU No. 25 Tahun 2009, LN. No. 112 Tahun 2009, TLN No. 5038.

Indonesia, Undang-Undang Ombudsman, UU No. 37 Tahun 2008, LN. 139, Tahun 2008, TLN. No. 4899.

Indonesia Undang-Undang Penetapan Peraturan Pemerintah Pengganti Undang-Undang Nomor 2 Tahun 2014 tentang Pemerintahan Daerah Menjadi Undang-Undang, UU No. 2 Tahun 2015, TLN. 24 Tahun 2015, TLN. No. 5589. 